\title{
Mucin overproduction in chronic inflammatory lung disease
}

\author{
Hans-Peter Hauber $\mathrm{MD}^{1,2}$, Susan C Foley $\mathrm{MD}^{1}$, Qutayba Hamid MD PhD ${ }^{1}$
}

\begin{abstract}
H-P Hauber, SC Foley, Q Hamid. Mucin overproduction in chronic inflammatory lung disease. Can Respir J 2006;13(6):327-335.
\end{abstract}

Mucus overproduction and hypersecretion are commonly observed in chronic inflammatory lung disease. Mucins are gel-forming glycoproteins that can be stimulated by a variety of mediators. The present review addresses the mechanisms involved in the upregulation of secreted mucins. Mucin induction by neutrophil elastase, bacteria, cytokines, growth factors, smoke and cystic fibrosis transmembrane conductance regulator malfunction are also discussed.

\section{La surproduction de mucine dans la pneumopathie inflammatoire chronique}

\begin{abstract}
La surproduction de mucus et l'hypersécrétion sont courantes en présence d'une pneumopathie inflammatoire chronique. Les mucines sont des glycoprotéines gélifiantes qui peuvent être stimulées par divers médiateurs. La présente analyse traite des mécanismes de régulation positive des mucines sécrétées. Est également exposée l'induction des mucines par l'élastase des neutrophiles, les bactéries, les cytokines, les facteurs de croissance, la fumée et la défaillance du régulateur de conductance transmembraneuse de la fibrose kystique.
\end{abstract}

Key Words: Bacteria; Cytokine; Lung; Mucin; Neutrophil elastase; Overproduction; Smoke

M ucus is an important component of both the physiological and pathological processes in airways. It protects, moisturizes and lubricates mucosal surfaces, and traps bacteria and other inhaled irritants for removal by mucociliary clearance. However, excessive production of airway mucus is a feature of chronic inflammatory lung diseases such as bronchial asthma, chronic obstructive pulmonary disease (COPD), bronchiectasis and cystic fibrosis (CF). Mucus hypersecretion results from hyperplasia and metaplasia of mucous cells, which lead to greater numbers of these cells being found throughout the airways, including the distal airways, where they are normally absent (1). The presence of neutrophil elastase, certain bacterial pathogens and altered cytokine patterns all contribute to excess airway mucus production. This overproduction and hypersecretion of mucus, in turn, contributes to airway obstruction and impairment of mucociliary clearance.

An understanding of the mechanisms that lead to mucus overproduction and secretion is therefore of great clinical interest. The present review provides insight into the mechanisms by which excessive mucus production is stimulated in chronic inflammatory lung disease, focusing mainly on enhanced gene expression and protein production of secretory mucins in the airways.

\section{MUCINS}

Mucus is formed within the airways by a polymeric matrix of large, oligomeric, gel-forming glycoproteins, called mucins. These gel-forming mucins are primarily responsible for the rheological properties of airway mucus (2). However, in disease states such as CF and chronic bronchitis, polymeric DNA and filamentous actin, two products of leukocyte lysis, contribute greatly to, and are the principal determinants of, the viscoelastic properties of the purulent sputum that is associated with these diseases $(3,4)$. The molecular weights of mucins range between $2 \times 10^{6} \mathrm{Da}$ and $40 \times 10^{6} \mathrm{Da}$, and they are composed of $50 \%$ to $85 \%$ carbohydrate (5-7). Each mucin contains an apomucin core that is enriched by hydroxyamino acids, namely, serine and threonine. These amino acids contain O-glycosylation sites for oligosaccharides (8-10). The number and length of these O-glycosylation domains vary among mucins, and each domain has a repeated series of sequences (ie, variable number of tandem repeats) (11-14). Thus, a single mucin gene can produce a set of diverse messenger RNA (mRNA) through alternate splicing during transcription.

The amount of protein generated by mucin mRNA can also be varied by mRNA stabilization, which may be observed following the treatment of cells with inflammatory mediators and cytokines (15). Furthermore, a wide diversity of posttranslational modifications can produce multiple peptides from each mucin transcript. Oligosaccharides are joined to the mucin protein core through an initial alpha-O-glycosidic linkage of $N$-acetyl-galactosamine (GalNAc) to the hydroxyl region of serine or threonine (16), and this linkage provides the starting point for branching oligosaccharide chains. Mucin O-glycosylation is accomplished by one of six uridine diphosphate-GalNAc-polypeptide-alpha-N-GalNAc-transferases $(17,18)$. Sulfate or neuramic acid moieties produces a polyanionic (ie, acidic) mucin molecule. There is wide mucin heterogeneity among and within individuals, which arises because of the differing lengths of mRNA in a single apomucin gene,

${ }^{1}$ Meakins-Christie Laboratories, McGill University, Montreal, Quebec; ${ }^{2}$ Department of Medicine, Research Center Borstel, Borstel, Germany

Correspondence: Dr Qutayba Hamid, Meakins-Christie Laboratories, 3626 St Urbain Street, Montreal, Quebec H2X 2 P2.

Telephone 514-398-3864 ext 00143, fax 514-398-7483, e-mail qutayba.hamid@mcgill.ca 


\begin{tabular}{l}
$\begin{array}{l}\text { TABLE } 1 \\
\text { Human mucins classified by protein backbone structures } \\
\text { encoded by mucin }(\boldsymbol{M U C}) \text { genes }\end{array}$ \\
$\begin{array}{l}\text { Mucins } \\
\text { Classification }\end{array}$ \\
\hline $\begin{array}{l}\text { Membrane-associated, TR+ } \\
\text { MUC1, MUC3A, MUC3B, MUC4, MUC11, } \\
\text { MUC12, MUC13, MUC16, MUC17, MUC20 } \\
\text { Secreted, TR+ } \\
\text { MUC2, MUC5AC, MUC5B, MUC6, MUC7, }\end{array}$ \\
$\begin{array}{l}\text { Mucins lacking TR } \\
\text { MUC15, MUC18 } M U C 19\end{array}$ \\
\hline
\end{tabular}

TR+ Tandem repeat present

the varying stability of transcripts and the various combinations of several hundred different carbohydrate chains in each peptide.

At present, 20 human mucin (MUC) genes have been identified (MUC1, MUC2, MUC3A, MUC3B, MUC4, MUC5AC, MUC5B, MUC6, MUC7, MUC8, MUC9, MUC11, MUC12, MUC13, MUC15, MUC16, MUC17, MUC18, MUC19 and MUC20) (19-36). The characteristic feature that distinguishes mucins from other glycoproteins is the presence of tandem repeat (TR) domains. However, MUC15 and MUC18 do not have TR domains, and it remains to be resolved as to whether a macromolecule indeed requires TR domains or only a significant degree of $\mathrm{O}$-glycosylation sites to be classified as a mucin. More than 20 rodent Muc genes have been described and confusion arises in the nomenclature; for example, murine $\mathrm{Mucl0}$ is the orthologue of the human MUC7 gene, and murine Muc14 is the homologue of a gene that encodes human endomucin-1/2. Mucins are classified based on their protein backbone structure, which is encoded by a MUC gene. The genes have been divided into two groups, namely, membrane-associated mucins and secreted mucins (Table 1). The majority of membrane-associated human mucin genes (MUC3A, MUC3B, MUC11, MUC12 and MUC17) are located in a cluster on chromosome 7 at locus 7q22 (29,33,37). Chromosome 3q29 provides the locus for another two genes, namely, MUC4 and MUC20, whereas MUC13 is at position 3q13.3. The remaining two membraneassociated mucin genes are located on chromosome 1 (MUC1) and chromosome 19 (MUC16).

Four of the genes encoding secreted mucins are located in a cluster on chromosome 11 at locus 11p15 (MUC2, MUC5AC, MUC5B and MUC6) $(38,39)$. The two human mucins that lack TR domains (MUC15 and MUC18) are also located on chromosome 11, at positions $11 \mathrm{p} 14.3$ and $11 \mathrm{q} 23.3$, respectively (31). The remaining secreted mucins are located on chromosome 12 (MUC8 and MUC19), chromosome 4 (MUC7) and chromosome 1 (MUC9) $(26-28,35)$. While the expression of MUC2 and MUC5AC are localized to the surface epithelial cells, MUC5B and MUC7 are mainly produced by submucosal glands.

The promoters of MUC2, MUC5AC and MUC5B contain typical TATA box motifs, and several transcription factor binding sites have been identified, including the following: for MUC2 - activator protein (AP)-1, AP-2, cyclic AMP response element-binding protein, CCAAT/enhancer binding protein and HC3; for MUC5AC - Sp1, AP-2, glucocorticoid receptor element, polyomavirus enhancer activator-3 and nuclear factor-kappa B (NF- $\kappa$ B); and for MUC5B - Sp1, NF- $\mathrm{BB}$, c-Myc and N-Myc (39-41). These binding sites provide possible targets for transcriptional regulation of MUC gene expression.
The present review focuses mainly on MUC5AC expression, because it is the predominant mucin secreted in the airways.

\section{INDUCTION OF MUCIN PRODUCTION BY NEUTROPHIL ELASTASE}

A neutrophilic pattern of inflammation is typically seen in the bronchoalveolar lavage fluid of patients with chronic inflammatory airway disease, including $\mathrm{CF}$, chronic bronchitis and bronchiectasis $(42,43)$. The presence of neutrophils in the sputum is directly correlated with impaired pulmonary function (44), suggesting a close link between neutrophilic inflammation and airway mucus obstruction.

Neutrophil elastase (EC 3.4.21.37), a serine protease that is released by neutrophils, is found in high concentrations in airway surface fluids of patients with chronic airway diseases $(42,43,45,46)$. This enzyme can impair mucociliary clearance by several mechanisms that ultimately lead to airway obstruction by mucus; for example, the enzyme can cause ciliary injury and impairment of function (47), thereby stimulating mucin production, secretion and release (48-50). Neutrophil elastase also leads to secretory cell metaplasia and hyperplasia within airways, as well as the accumulation of secretory granules (51).

Increased MUC5AC mRNA and protein expression due to neutrophil elastase has been demonstrated in vitro (52). Neutrophil elastase enhances MUC5AC mRNA stability and, thus, increases mRNA levels (52). Recent studies have also found that neutrophil elastase induces MUC5 AC gene expression via reactive oxygen species (ROS) $(53,54)$. Conversely, in vitro, antioxidants can inhibit elastase-induced MUC5AC gene expression (54). Moreover, there is evidence for the generation of ROS by neutrophil elastase (55), with several studies reporting that ROS increases mRNA stability $(56,57)$.

Neutrophil elastase has also been shown to cause mucin production through activation of the epidermal growth factor receptor (EGF-R) (55). The mechanism by which this process is initiated has recently been elucidated. The first step involves activation of dual oxidase 1 (Duox1) by neutrophil elastase to produce ROS (58); ROS are reported to be generated by NADPH oxidases (Nox) of phagocytes (59). Duox1 is a homologue of the core component of Nox, gp91 phox (60), and has been identified in human airway epithelial cells to produce ROS (58). When stimulated by neutrophil elastase, cytosolic components of Nox, p4 $7^{\text {phox }}$ and p67phox , are recruited to the plasma membrane to join Duox1 to form an active enzyme complex to generate ROS (58). This process is dependent on protein kinase $\mathrm{C}$ (58). ROS activates the latent form of tumour necrosis factor-alpha-converting enzyme (TACE), which, in turn, cleaves protransforming growth factor-alpha (pro-TGF- $\alpha$ ) into TGF- $\alpha$. Soluble TGF- $\alpha$ binds to and activates EGF-R, leading to mucin expression (see section on "Mucin induction by growth factors").

\section{BACTERIA-INDUCED MUCIN PRODUCTION}

Several studies have demonstrated that bacteria can induce mucus production. Staphylococcus aureus and Pseudomonas aeruginos $a$ are potent stimuli in CF patients $(61,62)$. Early studies using cell culture supernatants of $P$ aeruginosa revealed that lipopolysaccharides (LPS) (the major outer membrane component of Gram-negative bacteria) could upregulate transcription of the MUC2 gene in epithelial cells (61). Subsequent experiments showed that the $P$ aeruginosa-response element in 
the $5^{\prime}$-flanking region of the MUC2 gene contained overlapping CCAAT/enhancer binding protein and NF- $\mathrm{kB}$ sites (63). NF- $\mathrm{kB}$ was identified as an important binding site (62), and further studies found that the activation of NF- $\mathrm{kB}$ by $\mathrm{P}$ aeruginosa occurs via a Src-dependent Ras-mitogen-activated or extracellular signal-regulated protein kinase (MEK) 1/2extracellular signal-regulated protein kinase (ERK) 1/2-90 kDa ribosomal S6 kinase pathway (63).

Despite evidence for the involvement of LPS in the transcriptional activation of mucin by $\mathrm{P}$ aeruginosa, it is clear that the response induced by LPS does not account for that induced by the whole supernatant (62). The investigation of additional bacterial factors that might stimulate mucin production led to the discovery of a distinct yet overlapping pathway activated by the $P$ aeruginosa outer membrane protein flagellin (62). Flagellin is a major structural component of bacterial flagella, and it is required for chemotaxis, motility and nutrition in both Gram-positive and Gram-negative bacteria. $P$ aeruginosa flagellin can elicit host cell responses by binding to the glycolipid asialo GM1 (ASGM1) (64). Because ASGM1 lacks transmembrane and intracellular domains, it is not capable of directly interacting with cytoplasmic proteins (62). Using an in vitro system to investigate intracellular signalling, the mechanisms by which ASGM1 ligation stimulates the transcription of the MUC2 gene was studied. McNamara et al (65) showed that the binding of flagellin to ASGM1 causes the extracellular release of ATP, which then binds to a nucleotide receptor. Downstream events include G-protein activation and the cleavage of phosphatidylinositol 4,5-bisphosphate by phospholipase $\mathrm{C}$, which results in the formation of inositol 1,4,5-trisphosphate. Inositol 1,4,5-trisphosphate triggers mobilization of $\mathrm{Ca}^{2+}$ from intracellular stores $(65,66)$, which then binds to an unknown $\mathrm{Ca}^{2+}$-binding protein, leading to phosphorylation of MEK1/2 and ERK1/2, and the subsequent transcription of MUC2 (65). Although inhibitors of calcium metabolism have been found to inhibit the mucin response, only approximately 50\% inhibition was achieved when the mitogen-activated protein kinase (MAPK) pathway was blocked, suggesting alternative ERK-independent downstream events (65).

Gram-positive bacteria such as $S$ aureus or Streptococcus pyogenes can also induce MUC2 gene transcription in epithelial cells (62). Teichoic acid and peptidoglycan (PGN) are the major polysaccharides in Gram-positive cell walls. Teichoic acid may also be linked to a lipid moiety such as lipotechoic acid (LTA) (67). Direct administration of PGN and LTA to epithelial cell cultures showed that PGN was a weak mucin stimulus, whereas LTA was shown to specifically stimulate mucin production and was responsible for most of the MUC2inducing activity of Gram-positive bacteria (68). Gram-positive bacteria bind to human cells via the platelet-activating factor receptor (PAF-R) (69,70). LTA, like PAF, causes phosphorylation and internalization of PAF-R, and PAF-R antagonists, such as CV3988 and 1-O-hexadecyl-2-O-acetyl-sn-glycero-3phospho-(N,N,N)-trimethyl hexanolamine, block mucin induction by LTA. PAF itself has been shown to stimulate mucin transcription in a concentration-dependent manner (68), supporting the hypothesis that LTA stimulates PAF-R and thereby stimulates MUC2. PAF-R, a G-protein-coupled receptor, can potentially act through the transactivation of EGF-R (71-73). The transactivation of EGF-R by certain G-protein-coupled receptors requires a metalloproteinase that cleaves pro-heparinbinding EGF (72). In summary, PAF-R induces mucin via the transactivation of EGF-R, a process that involves the cleavage of pro-heparin-binding EGR by a metalloproteinase (72). The metalloproteinase involved in this process has been identified as ADAM 10 (a disintegrin and a metalloproteinase) (68). Although toll-like receptor (TLR) 2 and/or TLR4 have been implicated in LTA-induced responses of macrophages, dendritic cells and human embryonic kidney 293 cells (74-77), and despite the expression of both TLR2 and TLR4 on epithelial cells, no evidence could be obtained for their involvement in LTA-induced mucin transcription.

The exposure of bronchial explants to $P$ aeruginosa supernatants for $6 \mathrm{~h}$ in vitro led to an upregulation of MUC5AC mRNA. Furthermore, NCI-H292 epithelial cells exposed to $P$ aeruginosa exoproducts showed increased levels of mucin protein (78). The presence of $P$ aeruginosa in the airways of CF patients, and the elevation of MUC5AC mRNA and protein $(78,79)$ pinpoint the need for a better understanding of the transcriptional control of the MUC5 AC gene by $P$ aeruginosa. Induction of MUC5AC transcription by cell-free supernatants of $P$ aeruginosa or its exoproducts has been demonstrated in a cell culture model (40). This upregulation can be mimicked by LPS and blocked by the tyrosine kinase inhibitor genistein (40). In another study, supernatants from $P$ aeruginosa induced EGF-R and MUC5AC mRNA and protein expression, as well as p44/42 MAPK phosphorylation in NCI-H292 cells (80). Pretreatment with a selective EGF-R tyrosine kinase inhibitor completely inhibited MUC5AC mRNA and protein induction, thus demonstrating the involvement of EGF-R (80). It has also been shown that upregulation of MUC5AC gene expression can be induced by exoproducts from Gram-positive bacteria (78).

Nontypeable Haemophilus influenzae is frequently reported in COPD exacerbations (81) associated with increased mucus production. Bacterial cytoplasmic proteins from $\mathrm{H}$ influenzae upregulate MUC5AC maximally via p38, whereas surface membrane proteins have only a weak effect on this mucin gene (82). Given the strong inductive effect of bacterial cytoplasmic proteins on MUC5AC, one would expect that antibiotics that exert their effects through bacterial lysis would increase mucus production in the short term. Jono et al (83) noted that nontypeable $\mathrm{H}$ influenzae upregulates the MUC5AC gene via activation of the TLR2-MyD88-dependent p38 MAPK pathway.

In microarray expression analysis, Bordetella pertussis has been found to induce MUC2 mRNA in BEAS-2B cells (84). Further experiments showed that $B$ pertussis stimulates MUC2 and MUC5AC transcription in both a concentration- and time-dependent manner.

More recently, there have been data emerging suggesting that there are reduced rather than increased amounts of gelforming mucins (MUC5B and MUC5AC) in the sputum of CF patients compared with normal sputum or the sputum of chronic bronchitis patients. In one study, Henke et al (85) found that the volume/volume concentration of the gel-forming mucins was greatly decreased compared with normal sputum, but that the amount of DNA was greatly increased in CF sputum. The mucins from the different groups were found to have the same apparent size, suggesting that they had not been proteolytically digested in the CF samples. This decreased mucin secretion may actually increase susceptibility to bacterial infection in CF patients by facilitating communication between the epithelial surface and biofilm-causing organisms. 


\section{CYTOKINE-INDUCED MUCIN PRODUCTION}

A number of studies have shown that cytokines play an important role in mediating mucus overproduction and hypersecretion in lung disease. Specifically, T helper 2 (Th2)-type cytokines (eg, interleukin [IL]-4, IL-9 and IL-13) have been investigated as possible stimulators of mucus production.

IL-4 has been shown to induce MUC2 gene expression and mucus glycoconjugate production in a human airway cell culture model (86). In vivo, intranasal instillation of IL-4 in mice increased MUC5AC mRNA expression and goblet cell metaplasia (86). Transgenic mice overexpressing IL-4 were found to have hypertrophic, nonciliated cells in their conducting airways due, in part, to the accumulation of mucus glycoprotein. An increase in MUC5AC gene expression was also reported. In addition, elevated levels of mucus-positive staining material were found in the bronchoalveolar lavage fluid (87).

Exaggerated production of IL-13 is found in both atopic and nonatopic asthma $(88,89)$. IL-13 and IL-4 have overlapping effector profiles due to the sharing of receptor components of the multimeric IL-13 and IL-4 receptor complexes $(90,91)$. Goblet cell hyperplasia and mucus overproduction are observed in transgenic mice that selectively overexpress IL-13 in the lungs (92). In ovalbumin (OVA)-challenged A/J mice, as well as in OVA-challenged BALB/c mice, blocking IL-13 reduces the rise in goblet cells caused by antigens $(93,94)$. On the other hand, the direct delivery of IL-13 to the airways enhances mucus production (94).

Signal transducer and activator of transcription (STAT) 6 , which is essential for the development of allergen-induced experimental asthma (95), and which is increased in epithelial cells in asthma (96), is a critical signalling molecule that is activated by the binding of IL-13 to its receptor. STAT6deficient mice are protected from the pulmonary effects of IL-13, but restoration of STAT6 to epithelial cells alone is sufficient to cause mucus production (and airway hyperresponsiveness) without inflammation, fibrosis or other lung pathologies (97). The direct effects of IL-13 on epithelial cells are therefore involved in mucus overproduction.

IL-13 is reported to mediate a pathway for mucus induction by airway epithelial cells in conjunction with CD4 T cells and IL-9 (98). MUC5AC gene expression was found to be reduced after Th2 cell transfer to mice in the absence of IL-13 or IL-4 receptor alpha (IL-4R $\alpha$ ) signalling (98). Interestingly, mucus production could be stimulated in the absence of NF- $\mathrm{kB}$, whereas other studies showed that the inhibition of this transcription factor prevented GATA-3 and Th2-type cytokine expression (99). The IL-4R subunit IL-4R $\alpha$, which is shared by IL-4R and IL-13 receptor, plays a key role in Th2type cytokine-induced mucus production. Cohn et al (100) showed that the induction of airway eosinophilia and mucus were both blocked in IL-4R $\alpha^{-1-}$ transgenic mice. They also demonstrated that mucus production was not dependent on eosinophils.

The increased expression of IL-9 and its receptor have been reported in the bronchial mucosa of asthmatic patients (101). Longphre et al (102) showed that allergen-induced IL-9 could directly stimulate mucin (MUC5AC) transcription in a cell culture model using the mucoepidermoid cell line NCI-H292. Moreoever, IL-9 overexpression in transgenic mice is associated with elevated MUC2 and MUC5AC gene expression, as well as increased mucus in the airways (103). Direct administration of IL-9 to the lungs by intratracheal instillation induced mucin hypersecretion in mice (103), while the Th1type cytokine interferon-gamma decreased mucin production. Further evidence for the role of IL-9 in mucus overproduction came from a study by Kung et al (104) in which mice were sensitized to and challenged with OVA. As expected, sensitized and challenged mice displayed eosinophilia, epithelial damage and goblet cell hyperplasia. Intraperitoneal administration of an antimouse IL-9 monoclonal antibody reduced pulmonary eosinophilia, serum immunoglobulin E levels, airway epithelial damage, airway hyperresponsiveness and goblet cell hyperplasia (104).

The mechanisms by which IL-9 induces mucus production have been further elucidated. In the lungs of a murine model of asthma, expression of the calcium-activated chloride channel (mCLCA3) was associated with airway hyperresponsiveness and mucus hypersecretion (105). Furthermore, the introduction of mCLCA3, or its human counterpart hCLCA1, into NCI-H292 cells induced MUC5AC expression and mucus production in vitro (105). mCLCA3 is involved and has also been shown to be induced in the airway epithelium of IL-9 transgenic mice (106). This induction can be achieved by intratracheal adminstration of IL-9 or other Th2-type cyokines (IL-4 and IL-13), but not by interferongamma (106). Antigen exposure increased the mCLCA3 expression in F1 mice, and this effect could be suppressed by treatment with an anti-IL-9 neutralizing antibody (106). In vitro, hCLCA1 could be induced in human primary lung cells by Th2 (IL-9 and IL-4) treatment (106). In the bronchial epithelium of asthmatic patients, an upregulation of hCLCA1 in mucus-producing epithelium was compared with control subjects (107). A strong positive correlation was found between hCLCA1 mRNA and both IL-9 and the IL-9 receptor. Taken together, these data suggest that IL-9 (and other Th2-type cyokines) acts through hCLCA1, and that this protein may be, in part, responsible for mucus overproduction in bronchial asthma. Investigations from our own laboratory have demonstrated increased expression of both IL-9 and its receptor, as well as upregulation of hCLCA1, in patients with CF or COPD $(108,109)$. Recently, cleavage products of hCLCA 1 and mCLCA 3 were found to be present in bronchoalveolar lavage fluid taken from asthmatic patients and OVA-challenged mice (110). Therefore, hCLCA 1 and mCLCA3 may not be ion channels but rather mediator proteins. By blocking hCLCA1 with either niflumic acid (a chloride channel antagonist) or one of its analogues, MSI-2216, mucus expression may be reduced in human airway mucosa (111).

More recent evidence of the role of IL-9 in mucus overexpression comes from a study by Vermeer et al (112), who observed that this cytokine had little effect on fully differentiated, ciliated human airway epithelium. However, during repair processes (eg, after an injury), exposure to IL-9 resulted in goblet cell hyperplasia. The stage of differentiation of airway epithlium is also important in determining the effects of IL-9.

Recent studies have questioned the role of Th2-type cytokines as mucus-inducing factors. Most of the studies were performed on cell lines or in animal models, and the data on primary epithelial cells are minimal. Recently, IL-13 has been shown to decrease MUC5AC gene expression and mucin secretion in cultured nasal epithelial cells (113). In another study, Chen et al (114) tested a panel of cytokines on primary human tracheal epithelial cells. IL-6 and IL-17 were found to 
induce MUC5AC and MUC5B gene expression. IL-4 has been observed to decrease MUC5AC expression and secretion in normal human nasal epithelial cells (115), and to decrease MUC5AC and MUC5B expression in human bronchial epithelial cells (116). However, primary airway epithelial cells are typically taken from patients with underlying pulmonary disease, making it uncertain whether the cells have been affected by other cytokines and mediators. On the other hand, it may be possible that Th2-type cytokines increase the number of mucus cells only after longer periods of time.

Other cytokines, such as tumour necrosis factor-alpha (TNF- $\alpha$ ), IL-1, IL-5, IL-6, IL-10 and IL-17, have also been shown to increase mucus expression $(114,115,117-121)$. At present, the intracellular signalling pathways by which cytokines upregulate MUC gene expression are far from being fully understood. IL-6 induces MUC5B gene expression via ERK (114), and IL-17 stimulates mucin mRNA expression partly through IL-6 by acting in an autocrine/paracrine manner, and perhaps through Janus-activated kinase 2 (114). TNF- $\alpha$ and IL-1 have been shown to induce MUC gene expression via ERK or the p38 MAPK pathway in vitro (122). The activation of mitogen- and stress-activated protein kinase 1, cyclic AMP response element-binding protein and the cyclic AMP response element signalling cascade are crucial for intracellular mediation of MUC5AC gene expression (122). TNF- $\alpha$ may also induce MUC gene expression through NF- $\mathrm{kB}$ and Sp1 (123). IL-4, IL-13, IL-9 and IL-6 bind to their specific receptors, which, in turn, heteromerize with gamma c chains or glycoprotein 130 molecules to activate intracellular signalling (124). These cytokines act via the Janus-activated kinase/STAT pathway (125-127).

\section{MUCIN INDUCTION BY GROWTH FACTORS}

Growth factors are thought to be involved in goblet cell production and mucus overproduction because hypersecretory diseases are associated with abnormal epithelial cell growth and differentiation. Moreover, epithelial damage leads to repair and remodelling processes (128). The activation of EGF-R by its ligands, EGF or TGF- $\alpha$, increases MUC5AC mRNA expression in vitro, and MUC5AC mucin production and goblet cell metaplasia in vivo (129). It has been shown that the induction of MUC2 and MUC5AC via the activation of EGF-R is mediated through an EGF-R-Ras-Raf-ERK pathway (123). TGF- $\alpha$ plays a critical role in EGF-R phosphorylation, leading to MUC5AC production. Pro-TGF- $\alpha$ is cleaved by TACE into its active form (130), which has recently been demonstrated to increase shedding of TGF- $\alpha$, thereby upregulating MUC5AC expression (131). In that study, the knockout of TACE expression with interfering RNA inhibited phorbol-12-myristate-13-acetate-, $P$ aeruginosa supernatantand LPS-induced TGF- $\alpha$ shedding, as well as EGF-R phosphorylation and mucin production.

\section{OTHER MECHANISMS OF MUCIN OVERPRODUCTION}

\section{$\mathrm{CF}$ transmembrane conductance regulator malfunction is} associated with MUC1 overexpression

The role of the defective CF transmembrane conductance regulator (CFTR) in mucus overproduction in CF has not yet been defined. However, Gonzalez-Guerrico et al (132) reported a link between CFTR failure and MUC1 overexpression in this disease. Using a cultured cell line (derived from a
CF patient) with or without transfection of wild-type CFTR, the tyrosine kinase c-Src was identified as a CFTR-dependent gene (132). c-Src expression was noted to be increased in the absence of functioning CFTR. At present, it is not clear how a channel protein like CFTR might control gene expression. It is possible that chloride transport or phosphorylation induced by CFTR may lead to conformational changes of other membrane proteins, which may ultimately serve as signal transducers (132). Pathways that are sensitive to membrane potential changes may also be present. Moreover, a PSD95/Dlg/ZO-1 (PDZ)-binding domain that recognizes the C-terminal consensus sequence $-\mathrm{T}(\mathrm{K} / \mathrm{R}) \mathrm{L}$ has been identified in CFTR, and several other CFTR-associated proteins have been reported $(133,134)$. There is a strong possibility that CFTR may be a control protein, and because c-Src also modulates CFTR activity, this effect may operate in both directions (135). The expression of the MUC1 gene $(136,137)$ located on chromosome 1 is regulated by c-Src, providing a CFTR-c-Src-MUC1 link.

\section{Smoke-induced mucin expression}

Repetitive exposure to irritant stimuli like smoke can cause bronchitis and mucus overproduction. The major aldehydes, including formaldehyde, propionaldehyde and acrolein, have numerous indoor and outdoor sources $(138,139)$.

In Sprague-Dawley rats, exposure to acrolein caused increased MUC5AC mRNA expression and mucus hypersecretion in the trachea and lungs, whereas MUC2 mRNA expression was not significantly altered (140). These findings indicate that acrolein-induced mucus overproduction is due, at least initially, to upregulation of MUC5AC mRNA expression, rather than MUC2 mRNA expression. A concentration-dependent increase in MUC5AC mRNA expression has been observed following exposure of human airway cells (NCI-H292) to acrolein in vitro (15), suggesting that acrolein has a direct effect on epithelial cells. However, acrolein can also initiate mucus hypersecretion indirectly via acute and chronic inflammation, which is characterized by neutrophils and macrophages $(141,142)$. Neutrophil elastase can induce goblet cell metaplasia and is a potent secretagogue (51). Macrophages provide another source of mediators, such as IL-1, eicosanoids (eg, prostaglandin E2 and 15-hydroxyeicosatetraenoic acid) and macrophagederived mucus secretagogue-68, that can initiate mucus secretions $(117,143,144)$. A recent study reported the activation of TACE by cigarette smoke, thereby activating TGF- $\alpha$-dependent EGF-R phosphorylation and MUC5AC expression in NCI-H292 cells (145).

Acrolein can act directly as an electrophilic compound to deplete nonprotein sulfhydryl groups/glutathione in the respiratory epithelium $(146,147)$ or to inactivate metabolizing enzymes $(148,149)$. Despite limited knowledge about cisactivating and trans-activating elements regulating MUC5AC expression, electrophiles are known to activate gene expression via a mechanism involving glutathione depletion and the production of ROS (150).

Given the numerous compounds in cigarette smoke, substances other than acrolein may induce mucus overproduction. In fact, inflammation due to smoke may have an important effect on mucus production and secretion. In an animal model, cigarette smoke-induced airway secretory cell hyperplasia was inhibited by the nonsteroidal drug indomethacin, as well as by corticosteroids (151). 


\section{CONCLUSIONS}

Despite its clinical importance, our knowledge of the pathogenesis of mucus overproduction in chronic inflammatory lung disease remains limited. Although pathomechanisms that contribute to exaggerated mucin expression have been elucidated, the pathogenesis of mucus hypersecretion was not the focus of the present review. Secretory processes have recently been further defined and possible target sites for therapeutic intervention have been identified in animal studies (151-153). If these findings translate to humans, this may ultimately benefit patients by blocking excessive mucus production and mucus hypersecretion in chronic inflammatory lung disease.

ACKNOWLEDGEMENTS: Dr HP Hauber was supported by a GlaxoSmithKline/Canadian Lung Association/Canadian Institutes of Health Research fellowship.

\section{REFERENCES}

1. Perez-Vilar J, Sheehan JK, Randell SH. Making more MUCS. Am J Respir Cell Mol Biol 2003;28:267-70.

2. Litt M, Khan MA, Chakrin LW, Wardell P Jr, Christian P. The viscoelasticity of fractionated canine tracheal mucus. Biorheology 1974;11:111-7.

3. Perks B, Shute JK. DNA and actin bind and inhibit interleukin-8 function in cystic fibrosis sputa: In vitro effects of mucolytics. Am J Respir Crit Care Med 2000;162:1767-72.

4. Tang JX, Wen Q, Bennett A, et al. Anionic poly(amino acid)s dissolve F-actin and DNA bundles, enhance DNase activity, and reduce the viscosity of cystic fibrosis sputum. Am J Physiol Lung Cell Mol Physiol 2005;289:L599-605.

5. Lamblin G, Aubert JP, Perini JM, et al. Human respiratory mucins. Eur Respir J 1992;5:247-56.

6. Rose MC. Mucins: Structure, function, and role in pulmonary diseases. Am J Physiol 1992;263:L413-29.

7. Rose MC, Gendler SJ. Airway mucin genes and gene products. In: Rogers DF, Lethem MI, eds. Airway Mucus: Basic Mechanisms and Clinical Perspectives. Boston: Birkhauser Verlag, 1997:41-66.

8. Strous GJ, Dekker J. Mucin-type glycoproteins. Crit Rev Biochem Mol Biol 1992;27:57-92.

9. Verma M, Davidson EA. Mucin genes: Structure, expression and regulation. Glycoconj J 1994;11:172-9.

10. Woodward H, Horsey B, Bhavandan VP, Davidson EA. Isolation, purification, and properties of respiratory mucus glycoproteins. Biochemistry 1982;21:694-701.

11. Gendler S, Taylor-Papadimitriou J, Duhig T, Rothbard J, Burchell J. A highly immunogenic region of a human polymorphic epithelial mucin expressed by carcinomas is made up of tandem repeats. J Biol Chem 1988;263:12820-3.

12. Porchet N, Nguyen VC, Dufosse J, et al. Molecular cloning and chromosomal localization of a novel human tracheo-bronchial mucin cDNA containing tandemly repeated sequences of 48 base pairs. Biochem Biophys Res Commun 1991;175:414-22.

13. Pratt WS, Islam I, Swallow DM. Two additional polymorphisms within the hypervariable MUC1 gene: Association of alleles either side of the VNTR region. Ann Hum Genet 1996;60:21-8.

14. Shankar V, Gilmore MS, Elkins RC, Sachdev GP. A novel human airway mucin cDNA encodes a protein with unique tandem-repeat organization. Biochem J 1994;300:295-8.

15. Borchers MT, Carty MP, Leikauf GD. Regulation of human airway mucins by acrolein and inflammatory mediators. Am J Physiol 1999;276:L549-55.

16. Serengi E, Botti C, Massaron S, et al. Structure, function and gene expression of epithelial mucins. Tumori 1997;83:625-32.

17. Mandel U, Hassan H, Therkildsen MH, et al. Expression of polypeptide GalNAc-transferases in stratified epithelia and squamous cell carcinomas: Immunohistological evaluation using monoclonal antibodies to three members of the GalNAc-transferase family. Glycobiology 1999;9:43-52.

18. Kingsley PD, Hagen KG, Maltby KM, Zara J, Tabak LA. Diverse spatial expression patterns of UDP-GalNAc:polypeptide $\mathrm{N}$-acetylgalactosaminyl-transferase family member mRNAs during mouse development. Glycobiology 2000;10:1317-23.

19. Spicer AP, Parry G, Patton S, Gendler SJ. Molecular cloning and analysis of the mouse homologue of the tumor-associated mucin, MUC1, reveals conservation of potential O-glycosylation sites, transmembrane, and cytoplasmic domains and a loss of minisatellite-like polymorphism. J Biol Chem 1991;266:15099-109.

20. Gum JR Jr, Hicks JW, Toribara NW, Siddiki B, Kim YS. Molecular cloning of human intestinal mucin (MUC2) cDNA. Identification of the amino terminus and overall sequence similarity to prepro-von Willebrand factor. J Biol Chem 1994;269:2440-6.

21. Van Kliniken BJ, Van Dijken TC, Oussoren E, Buller HA, Dekker J, Einerhand AW. Molecular cloning of human MUC3 cDNA reveals a novel 59 amino acid tandem repeat region. Biochem Biophys Res Commun 1997;238:143-8.

22. Moniaux N, Nollet S, Porchet N, Degand P, Laine A, Aubert JP. Complete sequence of the human mucin MUC4: A putative cell membrane-associated mucin. Biochem J 1999;338:325-33.

23. Van de Bovenkamp JH, Hau CM, Strous GJ, Buller HA, Dekker J, Einerhand AW. Molecular cloning of human gastric mucin MUC5AC reveals conserved cysteine-rich D-domains and a putative leucine zipper motif. Biochem Biophys Res Commun 1998;245:853-9.

24. Keates AC, Nunes DP, Afdhal NH, Troxler RF, Offner GD. Molecular cloning of a major human gall bladder mucin: Complete C-terminal sequence and genomic organization of MUC5B. Biochem J 1997;324:295-303.

25. Ho SB, Roberton AM, Shekels LL, Lyftogt CT, Niehans GA, Toribara NW. Expression cloning of gastric mucin complementary DNA and localization of mucin gene expression. Gastroenterology 1995;109:735-47.

26. Bobek LA, Tsai H, Biesbrock AR, Levine MJ. Molecular cloning, sequence, and specificity of expression of the gene encoding the low molecular weight human salivary mucin (MUC7). J Biol Chem 1993;268:20563-9.

27. Shankar V, Pichan P, Eddy RL Jr, et al. Chromosomal localization of a human mucin gene (MUC8) and cloning of the cDNA corresponding to the carboxy terminus. Am J Respir Cell Mol Biol 1997;16:232-41.

28. Lapensee L, Paquette Y, Bleau G. Allelic polymorphism and chromosomal localization of the human oviductin gene (MUC9). Fertil Steril 1997;68:702-8.

29. Williams SJ, McGuckin MA, Gotley DC, Eyre HJ, Sutherland GR, Antalis TM. Two novel mucin genes down-regulated in colorectal cancer identified by differential display. Cancer Res 1999;59:4083-9.

30. Williams SJ, Wreschner DH, Tran M, Eyre HJ, Sutherland GR, McGuckin MA. MUC13, a novel human cell surface mucin expressed by epithelial and hematopoetic cells. J Biol Chem 2001;276:18327-36.

31. Pallesen LT, Berglund L, Rasmussen LK, Petersen TE, Rasmussen JT. Isolation and characterization of MUC15, a novel cell membraneassociated mucin. Eur J Biochem 2002;269:2755-63.

32. Yin BW, Llyod KO. Molecular cloning of the CA125 ovarian cancer antigen: Identification as a new mucin, MUC16. J Biol Chem 2001;276:27371-5.

33. Gum JR Jr, Crawley SC, Hicks JW, Szymkowski DE, Kim YS. MUC17, a novel membrane-tethered mucin. Biochem Biophys Res Commun 2002;291:466-75.

34. Sers C, Kirsch K, Rothbacher U, Riethmuller G, Johnson JP. Genomic organization of the melanoma-associated glycoprotein MUC18: Implications for the evolution of the immunoglobulin domains. Proc Natl Acad Sci USA 1993;90:8514-8.

35. Chen Y, Zhao YH, Kalaslavadi TB, et al. Genome-wide search and identification of a novel gel-forming mucin MUC19/Muc19 in glandular tissues. Am J Respir Cell Mol Biol 2004;30:155-65.

36. Higuchi T, Orita T, Nakanishi S, et al. Molecular cloning, genomic structure, and expression analysis of MUC20, a novel mucin protein, up-regulated in injured kidney. J Biol Chem 2004;279:1968-79.

37. Fox MF, Lahbib F, Pratt W. Regional localization of the intestinal mucin gene MUC3 to chromosome 7q22. Ann Hum Genet 1992;56:281-7.

38. Pigny P, Guyonnet-Duperat V, Hill AS, et al. Human mucin genes assigned to $11 \mathrm{p} 15.5$ : Identification and organization of a cluster of genes. Genomics 1996;38:340-52. 
39. Velcich A, Palumbo L, Selleri L, Evans G, Augenlicht L. Organization and regulatory aspects of the human intestinal mucin gene (MUC2) locus. J Biol Chem 1997;272:7968-76.

40. Li D, Gallup M, Fan N, Szymkowski DE, Basbaum CB. Cloning of the amino-terminal and 5 '-flanking region of the human MUC5AC mucin gene and transcriptional up-regulation by bacterial exoproducts. J Biol Chem 1998;273:6812-20.

41. Van Seuningen I, Perrais M, Pigny P, Porchet N, Aubert JP. Sequence of the 5 '-flanking region and promoter activity of the human mucin gene MUC5B in different phenotypes of colon cancer cells. Biochem J 2000;348:675-86.

42. Welsh MJ, Tsui LC, Boat TF, Beaudet AL. Cystic fibrosis. In: Scriver CR, Beaudet AL, Sly WS, Valle D, eds. The Metabolic and Molecular Bases of Inherited Diseases. New York: McGraw-Hill, 1995:3799-876.

43. Senior RM, Shapiro SD. Chronic obstructive pulmonary disease: Epidemiology, pathophysiology, and pathogenesis. In: Fishman AP, ed. Fishman's Pulmonary Diseases and Disorders. New York: McGraw-Hill, 1998:659-81.

44. Stanescu D, Sanna A, Veritier C, et al. Airways obstruction, chronic expectoration, and rapid decline of $\mathrm{FEV}_{1}$ in smokers are associated with increased levels of sputum neutrophils. Thorax 1996;51:267-71.

45. Konstan MW, Hilliard KA, Norvell TM, Berger M. Bronchoalveolar lavage findings in cystic fibrosis patients with stable, clinically mild lung disease suggest ongoing infection and inflammation. Am J Respir Crit Care Med 1994;150:448-54. (Erratum in 1995;151:260).

46. Khan TZ, Wagener JS, Bost T, Martinez J, Accurso F, Riches DW. Early pulmonary inflammation in infants with cystic fibrosis. Am J Respir Crit Care Med 1995;151:1075-82.

47. Amitani R, Wilson R, Rutman A, et al. Effects of human neutrophil elastase and Pseudomonas aeruginosa proteinases on human respiratory epithelium. Am J Respir Cell Mol Biol 1991;4:26-32.

48. Kim KC, Wasano K, Niles RM, Schuster JE, Stone PJ, Brody JS. Human neutrophil elastase releases cell surface mucins from primary cultures of hamster tracheal epithelial cells. Proc Natl Acad Sci USA 1987;84:9304-8.

49. Fahy JV, Schuster A, Ueki I, Boushey HA, Nadel JA. Mucus hypersecretion in bronchiectasis. The role of neutrophil proteases. Am Rev Respir Dis 1992;146:1430-3.

50. Lundgren JD, Rieves RD, Mullol J, Logun C, Shelhammer JH. The effect of neutrophil protenase enzymes on the release of mucus from feline and human airway cultures. Respir Med 1994;88:511-8.

51. Breuer R, Christensen TG, Lucey EC, Stone PJ, Snider GL. An ultrastructural morphometric analysis of elastase-treated hamster bronchi shows discharge followed by progressive accumulation of secretory granules. Am Rev Respir Dis 1987;136:698-703.

52. Voynow JA, Young LR, Wang Y, Horger T, Rose MC, Fischer BM. Neutrophil elastase increases MUC5AC mRNA and protein expression in respiratory epithelial cells. Am J Physiol 1999;276:L835-43.

53. Fischer B, Voynow J. Neutrophil elastase induces MUC5AC messenger RNA expression by an oxidant-dependent mechanism. Chest 2000;117(Suppl 1):317S-20S

54. Fischer BM, Voynow JA. Neutrophil elastase induces MUC5AC gene expression in airway epithelium via a pathway involving reactive oxygen species. Am J Respir Cell Mol Biol 2002;26:447-52.

55. Kohri K, Ueki IF, Nadel JA. Neutrophil elastase induces mucin production by ligand-dependent epidermal growth factor receptor activation. Am J Physiol Lung Cell Mol Physiol 2002;283:L531-40.

56. Kuroki M, Voest EE, Amano S, et al. Reactive oxygen intermediates increase vascular endothelial growth factor expression in vitro and in vivo. J Clin Invest 1996;98:1667-75.

57. Esposito F, Cuccovillo F, Vanoni M, et al. Redox-mediated regulation of $\mathrm{p} 21^{\text {waf1/cip } 1}$ expression involves a post-transcriptional mechanism and activation of the mitogen-activated protein kinase pathway. Eur J Biochem 1997;245:730-7.

58. Shao MX, Nadel JA. Dual oxidase 1-dependent MUC5AC mucin expression in cultured human airway epithelial cells. Proc Natl Acad Sci USA 2005;102:767-72.

59. Babior BM. The respiratory burst oxidase. Curr Opin Hematol 1995;2:55-60.
60. Geiszt M, Witta J, Baffi J, Lekstrom K, Leto TL. Dual oxidases represent novel hydrogen peroxide sources supporting mucosal surface host defense. FASEB J 2003;17:1502-4.

61. Li JD, Dohrman AF, Gallup M, et al. Transcriptional activation of mucin by Pseudomonas aeruginosa lipopolysaccharide in the pathogenesis of cystic fibrosis lung disease. Proc Natl Acad Sci USA 1997;94:967-72.

62. McNamara N, Basbaum C. Signaling networks controlling mucin production in response to Gram-positive and Gram-negative bacteria. Glycoconj J 2001;18:715-22.

63. Li JD, Feng W, Gallup M, et al. Activation of NF-kappaB via a Src-dependent Ras-MAPK-pp90rsk pathway is required for Pseudomonas aeruginosa-induced mucin overproduction in epithelial cells. Proc Natl Acad Sci USA 1998;95:5718-23.

64. Feldman M, Bryan R, Rajan S, et al. Role of flagella in pathogenesis of Pseudomonas aeruginosa pulmonary infection. Infect Immun 1998;66:43-51.

65. McNamara N, Khong A, McKemy D, et al. ATP transduces signals from ASGM1, a glycolipid that functions as a bacterial receptor. Proc Natl Acad Sci USA 2001;98:9086-91.

66. Berridge MJ. Inositol trisphosphate and calcium signalling. Nature 1993;361:315-25.

67. Salyers AA, Whitt DD. Bacterial Pathogenesis: A Molecular Approach. Washington, DC: ASM Press, 1994:341.

68. Lemjabbar H, Basbaum C. Platelet-activating factor receptor and ADAM10 mediate responses to Staphylococcus aureus in epithelial cells. Nat Med 2002;8:41-6.

69. Cundell D, Gerard N, Gerard C, Idanpaan-Heikkila I, Tuomanen E. Streptococcus pneumoniae anchor to activated human cells by the receptor for platelet-activating factor. Nature 1995;377:435-8.

70. Cundell DR, Gerard C, Idanpaan-Heikkila I, Tuomanen EI, Gerard NP. PAf receptor anchors Streptococcus pneumoniae to activated human endothelial cells. Adv Exp Med Biol 1996;416:89-94.

71. Daub H, Weiss FU, Wallasch C, Ullrich A. Role of transactivation of the EGF receptor in signalling by G-protein-coupled receptors. Nature 1996;379:557-60.

72. Prenzel N, Zwick E, Daub H, et al. EGF receptor transactivation by G-protein-coupled receptors requires metalloproteinase cleavage of proHB-EGF. Nature 1999;402:884-8.

73. Maudsley S, Pierce KL, Zamah AM, et al. The beta(2)-adrenergic receptor mediates extracellular signal-regulated kinase activation via assembly of a multi-receptor complex with the epidermal growth factor receptor. J Biol Chem 2000;275:9572-80.

74. Schwandner R, Dziarski R, Wesche H, Rothe M, Kirschning C. Peptidoglycan- and lipoteichoic acid-induced cell activation is mediated by toll-like receptor 2. J Biol Chem 1999;274:17406-9.

75. Takeuchi O, Hoshino K, Kawai T, et al. Differential roles of TLR2 and TLR4 in recognition of Gram-negative and Gram-positive bacterial cell wall components. Immunity 1999;11:443-51.

76. Michelsen K, Aicher A, Mohaupt M, et al. The role of toll-like receptors (TLRs) in bacteria-induced maturation of murine dendritic cells (DCs). Peptidoglycan and lipoteichoic acid are inducers of DC maturation and require TLR2. J Biol Chem 2001;276:25680-6.

77. Opitz B, Schroder N, Spreitzer I, et al. Toll-like receptor-2 mediates Treponema glycolipid and lipoteichoic acid-induced NF-kappaB translocation. J Biol Chem 2001;276:22041-7.

78. Dohrman A, Miyata S, Gallup M, et al. Mucin gene (MUC 2 and MUC 5AC) upregulation by Gram-positive and Gram-negative bacteria. Biochim Biophys Acta 1998;1406:251-9.

79. Groneberg DA, Eynott PR, Oates T, et al. Expression of MUC5AC and MUC5B mucins in normal and cystic fibrosis lung. Resp Med 2002;96:81-6.

80. Kohri K, Ueki IF, Shim JJ, et al. Pseudomonas aeruginosa induces MUC5AC production via epidermal growth factor receptor. Eur Respir J 2002;20:1263-70.

81. Moxon ER. The carrier state: Haemophilus influenzae. J Antimicrob Chemother 1986;18(Suppl A):17-24.

82. Wang B, Lim DJ, Han J, Kim YS, Basbaum CB, Li JD. Novel cytoplasmic proteins of nontypeable Haemophilus influenzae up-regulate human MUC5AC mucin transcription via a positive p38 mitogen-activated protein kinase pathway and a negative phosphoinositide 3-kinase-Akt pathway. J Biol Chem 2002;277:949-57.

83. Jono $\mathrm{H}, \mathrm{Xu} \mathrm{H}$, Kai $\mathrm{H}$, et al. Transforming growth factor-beta-Smad signaling pathway negatively regulates nontypeable Haemophilus 
influenzae-induced MUC5AC mucin transcription via mitogenactivated protein kinase (MAPK) phosphatase-1-dependent inhibition of p38 MAPK. J Biol Chem 2003;278:27811-9.

84. Belcher CE, Drenkow J, Kehoe B, et al. The transcriptional responses of respiratory epithelial cells to Bordetella pertussis reveal host defensive and pathogen counter-defensive strategies. Proc Natl Acad Sci USA 2000;97:13847-52.

85. Henke MO, Renner A, Huber RM, Seeds MC, Rubin BK. MUC5AC and MUC5B mucins are decreased in cystic fibrosis airway secretions. Am J Respir Mol Cell Biol 2004;31:86-91.

86. Dabbagh K, Takeyama K, Lee HM, Ueki IF, Lausier JA, Nadel JA. IL-4 induces mucin gene expression and goblet cell metaplasia in vitro and in vivo. J Immunol 1999;162:6233-7.

87. Temann UA, Prasad B, Gallup MW, et al. A novel role for murine IL-4 in vivo: Induction of MUC5AC gene expression and mucin hypersecretion. Am J Respir Cell Mol Biol 1997;16:471-8.

88. Kotsimbos TC, Ernst P, Hamid QA. Interleukin-13 and interleukin-4 are coexpressed in atopic asthma. Proc Assoc Am Physicians 1996;108:368-73

89. Humbert M, Durham SR, Kimmitt P, et al. Elevated expression of messenger ribonucleic acid encoding IL-13 in the bronchial mucosa of atopic and nonatopic subjects with asthma. J Allergy Clin Immunol 1997;99:657-65.

90. de Vries J. The role of IL-13 and its receptor in allergy and inflammatory responses. J Allergy Clin Immunol 1998;102:165-9.

91. Murata T, Taguchi J, Puri RK. Interleukin-13 receptor alpha' but not alpha chain: A functional component of interleukin-4 receptors. Blood 1998;91:3884-91.

92. Zhu Z, Homer RJ, Wang Z, et al. Pulmonary expression of interleukin-13 causes inflammation, mucus hypersecretion, subepithelial fibrosis, physiologic abnormalities, and eotaxin production. J Clin Invest 1999;103:779-88.

93. Wills-Karp M, Luyimbazi J, Xu X, et al. Interleukin-13: Central mediator of allergic asthma. Science 1998;282:2258-61.

94. Grünig G, Warnock M, Wakil AE, et al. Requirement for IL-13 independently of IL-4 in experimental asthma. Science 1998;282:2261-3

95. Kuperman D, Schofield B, Wills-Karp M, Grusby MJ. Signal transducer and activator of transcription factor 6 (Stat6)-deficient mice are protected from antigen-induced airway hyperresponsiveness and mucus production. J Exp Med $1998 ; 187: 939-48$

96. Mullings RE, Wilson SJ, Puddicombe SM, et al. Signal transducer and activator of transrciption 6 (STAT-6) expression and function in asthmatic bronchial epithelium. J Allergy Clin Immunol 2001;108:832-8

97. Kuperman DA, Huang X, Koth LL, et al. Direct effects of interleukin-13 on epithelial cells cause airway hyperreactivity and mucus overproduction in asthma. Nat Med 2002;8:885-9.

98. Whittaker L, Niu N, Temann UA, et al. Interleukin-13 mediates a fundamental pathway for airway epithelial mucus induced by CD4 T cells and interleukin-9. Am J Respir Cell Mol Biol 2002;27:593-602.

99. Das J, Chen CH, Yang L, Cohn L, Ray P, Ray A. A critical role for NF-kappa B in GATA3 expression and TH2 differentiation in allergic airway inflammation. Nat Immunol 2001;2:45-50.

100. Cohn L, Homer RJ, MacLeod H, Mohrs M, Brombacher F, Bottomly K. Th2-induced airway mucus production is dependent on IL-4Ralpha, but not on eosinophils. J Immunol 1999;162:6178-83.

101. Shimbara A, Christodoupoulos P, Soussi-Gounni A, et al. IL-9 and its receptor in allergic and nonallergic lung disease: Increased expression in asthma. J Allergy Clin Immunol 1999;104:108-15.

102. Longphre M, Li D, Gallup M, et al. Allergen-induced IL-9 directly stimulates mucin transcription in respiratory epithelial cells. J Clin Invest 1999;104:1375-82

103. Louahed J, Toda M, Jen J, et al. Interleukin-9 upregulates mucus expression in the airways. Am J Respir Cell Mol Biol 2000;22:649-56

104. Kung TT, Lou B, Crawley Y, et al. Effect of anti-mIL-9 antibody on the development of pulmonary inflammation and airway hyperresponsiveness in allergic mice. Am J Respir Cell Mol Biol 2001;25:600-5.

105. Nakanishi A, Morita S, Iwashita H, et al. Role of gob-5 in mucus overproduction and airway hyperresponsiveness in asthma. Proc Natl Acad Sci USA 2001;98:5175-80.

106. Zhou Y, Dong Q, Louahed J, et al. Characterization of a calciumactivated chloride channel as a shared target of Th2 cytokine pathways and its potential involvement in asthma. Am J Respir Cell Mol Biol 2001;25:486-91

107. Toda M, Tulic MK, Levitt RC, Hamid Q. A calcium-activated chloride channel (hCLCA1) is strongly related to IL-9 expression and mucus production in bronchial epithelium of patients with asthma. J Allergy Clin Immunol 2002;109:246-50.

108. Hauber HP, Tsicopoulos A, Wallaert B, et al. Expression of hCLCA1 in cystic fibrosis lungs is associated with mucus overproduction. Eur Respir J 2004;23:846-50.

109. Hauber HP, Bergeron C, Tsicopoulos A, et al. Increased expression of the calcium-activated chloride channel in hCLCA1 in airways of patients with obstructive chronic bronchitis. Can Respir J 2005;12:143-6.

110. Gibson A, Lewis AP, Affleck K, Meldrum E, Thompson N. hCLCA 1 and mCLCA3 are secreted non-integral membrane proteins and therefore are not ion channels. J Biol Chem 2005;280:27205-12.

111. Hauber HP, Daigneault P, Frenkiel S, et al. Niflumic acid and MSI-2216 reduce TNF-alpha-induced mucin expression in human airway mucosa. J Allergy Clin Immunol 2005;115:266-71.

112. Vermeer PA, Harson R, Einwalter LA, Moninger T, Zabner J. Interleukin-9 induces goblet cell hyperplasia during the repair of human airway epithelia. Am J Respir Cell Mol Biol 2003;28:286-95.

113. Kim CH, Song KS, Koo JS, et al. IL-13 suppresses MUC5AC gene expression and mucin secretion in nasal epithelial cells. Acta Otolaryngol 2002;122:638-43.

114. Chen Y, Thai P, Zhao YH, Ho YS, DeSouza MM, Wu R. Stimulation of airway mucin gene expression by interleukin (IL)-17 through IL-6 paracrine/autocrine loop. J Biol Chem 2003;278:17036-43.

115. Seong JK, Koo JS, Lee WJ, et al. Upregulation of MUC8 and downregulation of MUC5AC by inflammatory mediators in human nasal polyps and cultured nasal epithelium. Acta Otolaryngol 2002;122:401-7.

116. Jayawickreme SP, Gray T, Nettesheim P, Eling T. Regulation of 15-lipooxygenase expression and mucus secretion by IL-4 in human bronchial epithelial cells. Am J Physiol 1999;276:L596-603.

117. Cohan VL, Scott AL, Dinarello CA, Prendergast RA. Interleukin-1 is a mucus secretagogue. Cell Immunol 1991;136:425-34.

118. Kim YD, Kwon EJ, Kwon TK, Baek SH, Song SY, Suh JS Regulation of IL-1beta mediated MUC2 gene in NCI-H292 human airway epithelial cells. Biochem Biophys Res Commun 2000;274:112-16

119. Lee JJ, McGarry MP, Denzler KL, et al. Interleukin-5 expression in the lung epithelium of transgenic mice leads to pulmonary changes pathognomonic of asthma. J Exp Med 1997;185:2143-56.

120. Levine SJ, Larivee P, Logun C, Angus CW, Ognibene FP, Shelhamer JH. Tumor necrosis factor-alpha induces mucin hypersecretion and MUC-2 gene expression by human airway epithelial cells. Am J Respir Cell Mol Biol 1995;12:196-204.

121. Lee CG, Homer RJ, Cohn L, et al. Transgenic overexpression of interleukin (IL)-10 in the lung causes mucus metaplasia, tissue inflammation, and airway remodeling via IL-13-dependent and -independent pathways. J Biol Chem 2002;277:35466-74.

122. Song KS, Lee WJ, Chung KC, et al. Interleukin-1 beta and tumor necrosis factor-alpha induce MUC5AC overexpression through a mechanism involving ERK/p38 mitogen-activated protein kinases-MSK1-CREB activation in human airway epithelial cells. J Biol Chem 2003;278:23243-50.

123. Perrais M, Pigny P, Copin MC, Aubert JP, Van Seuningen I. Induction of MUC2 and MUC5AC mucins by factors of the epidermal growth factor (EGF) family is mediated by EGF receptor/Ras/Raf/extracellular signal-regulated kinase cascade and Sp1. J Biol Chem 2002;277:32258-67.

124. Mueller TD, Zhang JL, Sebald W, Duschl A. Structure, binding, and antagonists in the IL-4/IL-13 receptor system. Biochim Biophys Acta 2002;1592:237-50

125. Murata T, Taguchi J, Puri RK, Mohri H. Sharing of receptor subunits and signal transduction pathway between the IL-4 and IL-13 receptor system. Int J Hematol 1999;69:13-20.

126. Demoulin JB, Renauld JC. Interleukin 9 and its receptor: An overview of structure and function. Int Rev Immunol 1998;16:345-64.

127. Kamimura D, Ishihara K, Hirano T. IL-6 signal transduction and its physiological roles: The signal orchestration model. Rev Physiol Biochem Pharmacol 2003;149:1-38. 
128. Davies DE, Polosa R, Puddicombe SM, Richter A, Holgate ST. The epidermal growth factor receptor and its ligand family: Their potential role in repair and remodeling in asthma. Allergy 1999;54:771-83.

129. Takeyama K, Dabbagh K, Lee HM, et al. Epidermal growth factor system regulates mucin production in airways. Proc Natl Acad Sci USA 1999:96:3081-6.

130. Peschon JJ, Slack JL, Reddy P, et al. An essential role for ectodomain shedding in mammalian development. Science 1998;282:1281-4.

131. Shao MX, Ueki IF, Nadel JA. Tumor necrosis factor alphaconverting enzyme mediates MUC5AC mucin expression in cultured human airway epithelial cells. Proc Natl Acad Sci USA 2003; 100:11618-23.

132. Gonzalez-Guerrico AM, Cafferata EG, Radrizzani M, et al. Tyrosine kinase c-Src constitutes a bridge between cystic fibrosis transmembrane regulator channel failure and MUC1 overexpression in cystic fibrosis. J Biol Chem 2002;19:17239-47.

133. Mohler PJ, Kreda SM, Boucher RC, Sudol M, Stutts MJ, Milgram SL. Yes-associated protein 65 localizes p62(c-Yes) to the apical compartment of airway epithelia by association with EBP50. J Cell Biol 1999;147:879-90.

134. Moyer BD, Denton J, Karlson KH, et al. A PDZ-interacting domain in CFTR is an apical membrane polarization signal. J Clin Invest 1999;104:1353-61.

135. Fischer H, Machen TE. The tyrosine kinase p60c-src regulates the fast gate of the cystic fibrosis transmembrane conductance regulator chloride channel. Biophys J 1996;71:3073-82

136. Li Y, Ren J, Yu W, et al. The epidermal growth factor receptor regulates interaction of the human DF3/MUC1 carcinoma antigen with c-Src and beta-catenin. J Biol Chem 2001;276:35239-42.

137. Li Y, Kuwahara H, Ren J, Wen G, Kufe D. The c-Scr tyrosine kinase regulates signaling of the human DF3/MUC1 carcinomaassociated antigen with GSK3beta and beta-caenin. J Biol Chem 2001;276:6061-4

138. Leikauf GD. Mechanisms of aldehyde-induced bronchial reactivity: Role of airway epithelium. Res Rep Health Eff Inst 1992;49:1-35.

139. US Environmental Protection Agency. Toxics in the Community: National and Local Perspectives. Washington, DC: US Environmental Protection Agency, 1991.

140. Borchers MT, Wert SE, Leikauf GD. Acrolein-induced MUC5AC expression in rat airways. Am J Physiol 1998;274:L573-81.
141. Leikauf GD, Leming LM, O’Donnell JR, Doupnik CA. Bronchial responsiveness and inflammation in guinea pigs exposed to acrolein. J Appl Physiol 1989;66:171-8

142. Kutzman RS, Popenoe EA, Schmaeler M, Drew RT. Changes in rat lung structure and composition as a result of subchronic exposure to acrolein. Toxicology 1985;34:139-51.

143. Marom Z, Shelhamer JH, Sun F, Kaliner M. Human airway monohydroxyeicosatetraenoic acid generation and release. J Clin Invest 1983;72:122-7.

144. Enss ML, Wagner S, Schmidt-Wittig U, Heim HK, Beil W, Hedrich HJ. Effects of PGE2 on amount and composition of high molecular weight glycoproteins released by human gastric mucous cells in primary culture. Prostaglandins Leukot Essent Fatty Acids 1997;56:93-8.

145. Shao MX, Nakanaga T, Nadel JA. Cigarette smoke induces MUC5AC mucin overproduction via tumor necrosis factor-alphaconverting enzyme in human airway epithelial (NCI-H292) cells. Am J Physiol Lung Cell Mol Physiol 2004;287:L420-7.

146. Lam CW, Casanova M, Heck HD. Depletion of nasal mucosal glutathione by acrolein and enhancement of formaldehyde-induced DNA-protein cross-linking by simultaneous exposure to acrolein. Arch Toxicol 1985;58:67-71.

147. Grafstrom RC, Dypbukt JM, Willey JC, et al. Pathobiological effects of acrolein in cultured human bronchial epithelial cells. Cancer Res 1988;48:1717-21.

148. Mitchell DY, Petersen DR. Inhibition of rat liver aldehyde dehydrogenases by acrolein. Drug Metab Dispos 1988;16:37-42.

149. Cooper KO, Witz G, Witmer C. The effects of alpha, beta-unsaturated aldehydes on hepatic thiols and thiol-containing enzymes. Fundam Appl Toxicol 1992;19:343-9.

150. Bergelson S, Pinkus R, Daniel V. Induction of AP-1 (Fos/Jun) by chemical agents mediates activation of glutathione S-transferase and quinone reductase gene expression. Oncogene 1994;9:565-7.

151. Rogers DF, Jeffery PK. Inhibition of cigarette smoke-induced airway secretory cell hyperplasia by indomethacin, dexamethasone, prednisolone, or hydrocortisone in the rat. Exp Lung Res 1986;10:285-98

152. Li Y, Martin LD, Spizz G, Adler KB. MARCKS protein is a key molecule regulating mucin secretion by human airway epithelial cells in vitro. J Biol Chem 2001;276:40982-90.

153. Singer M, Martin LD, Vargaftig BB, et al. A MARCKS-related peptide blocks mucus hypersecretion in a mouse model of asthma. Nat Med 2004;10:193-6 


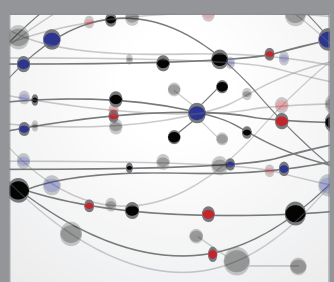

The Scientific World Journal
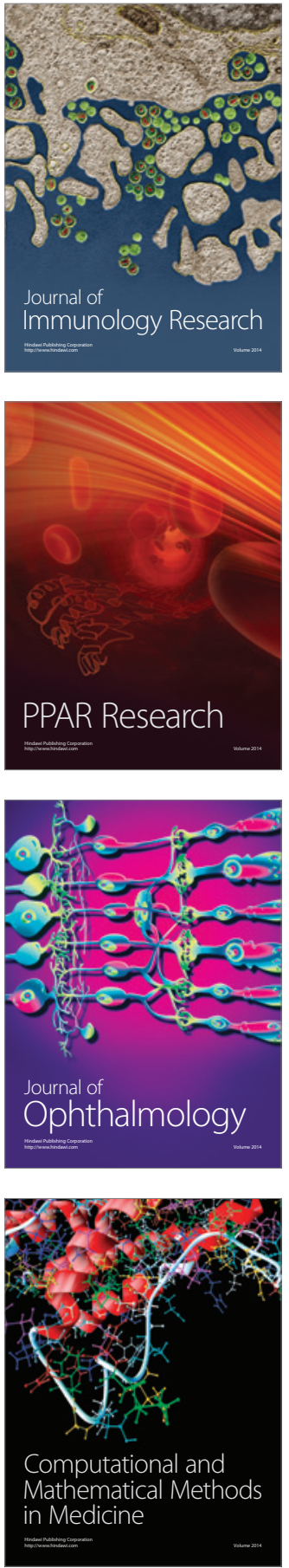

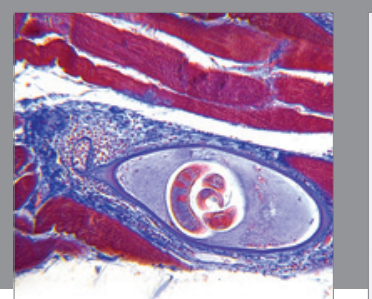

Gastroenterology Research and Practice

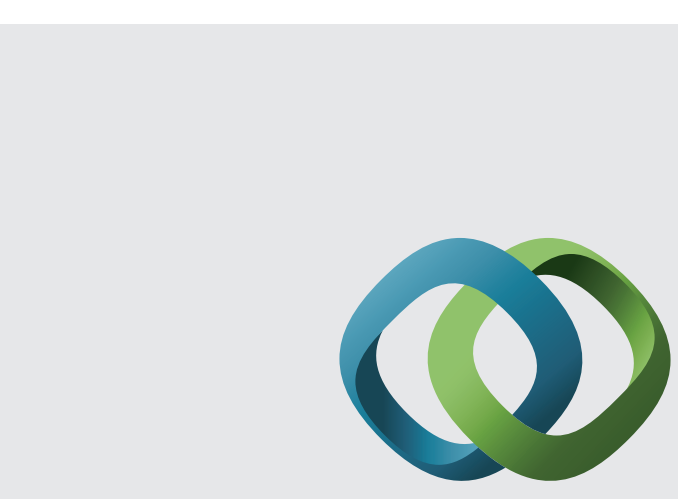

\section{Hindawi}

Submit your manuscripts at

http://www.hindawi.com
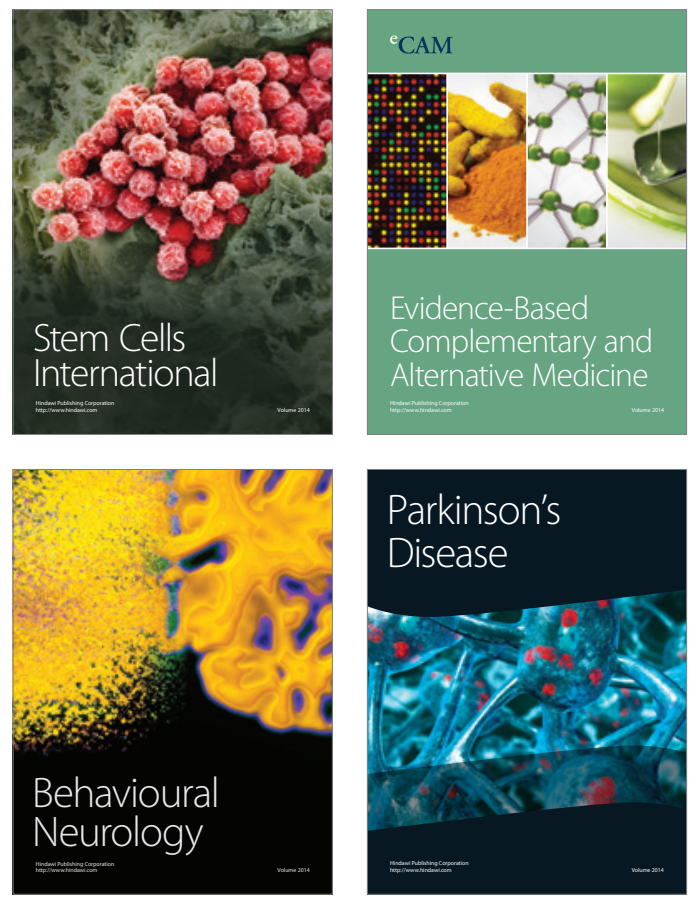
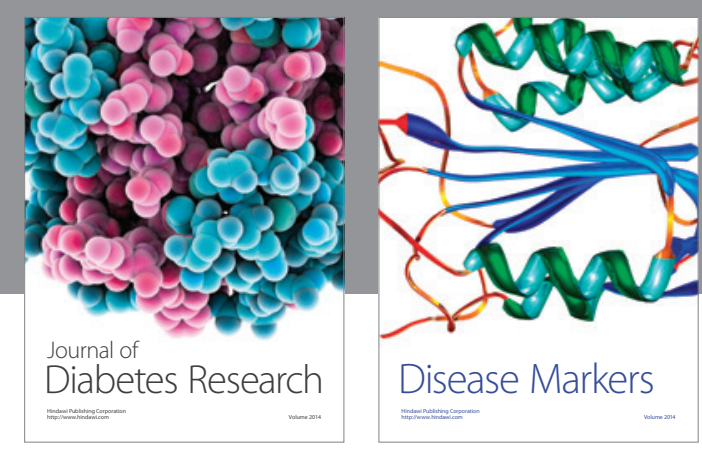

Disease Markers
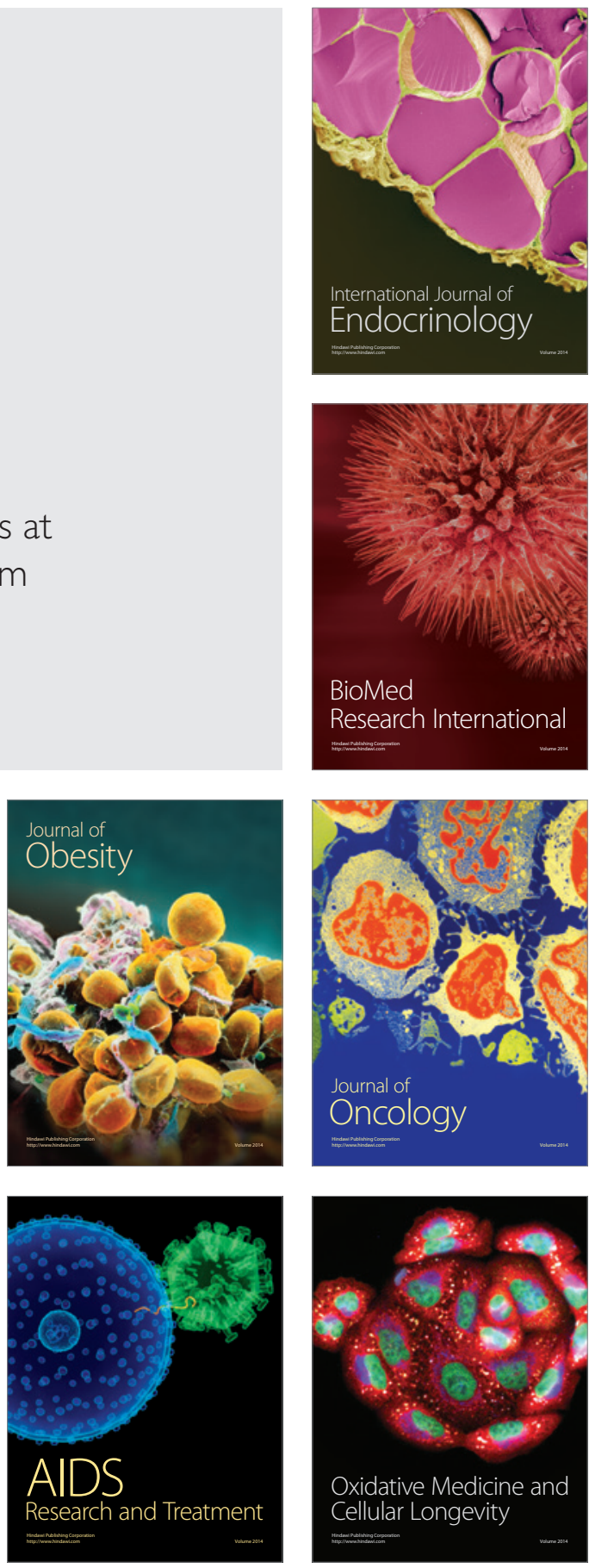